\title{
News, Notes, and Queries
}

\section{THE WORSHIPFUL SOCIETY OF APOTHECARIES OF LONDON \\ FACULTY OF THE HISTORY AND PHILOSOPHY OF MEDICINE AND PHARMACY}

At the Annual General Meeting of the Faculty, held at Apothecaries' Hall on 9 April 1986, the following Officers were elected for the 1986-87 session: President, Dr Alex Sakula; Deputy-President, Professor Sydney Selwyn; Honorary Secretary, Mr Robin Price.

Details of membership and eponymous lectures may be obtained from the Honorary Secretary of the Faculty, Apothecaries' Hall, Black Friars Lane, London, EC4V 6EJ.

\section{SYMPOSIUM ON 'CLINICAL TEACHING, PAST AND PRESENT'}

The Medical Faculty of Leiden University will commemorate the founding of clinical teaching in 1636 with an offical ceremony. Under the auspices of the International Academy of the History of Medicine, a symposium will be organized on 'Clinical Teaching, Past and Present' on 27-29 August 1986. The major topics will be the chronology of innovating ideas and the reception of these ideas in different countries since 1880. Lectures will be given by invited speakers on both historical and modern aspects of clinical teaching. Further information: Dr. H. Beukers (secretary), Metamedica, Division of the History of Medicine, P.O. Box 9603, 2300 RC Leiden, The Netherlands.

\section{LIVERPOOL MEDICAL HISTORY SOCIETY}

Readers may be interested to learn that a Liverpool Medical History Society was formed in June 1984, its aims being "to encourage, in every possible way, the advancement of knowledge of the history of medicine within its membership and the community." Membership is open to all persons paying the annual subscription of £2.00. Members are drawn from members of the medical and allied professions, staff and students of the University of Liverpool, etc. Normally five meetings are held each Session, two of which are held jointly with the Liverpool Medical Students' Society and with the Manchester Medical History Group. In the current Session the papers given or to be given to the Society include Dr Irvine Loudon (Wellcome Unit for the History of Medicine, Oxford) on 'The Enigma of Maternal Mortality, 1700-1935', Dr Christopher Lawrence (Wellcome Institute, London) on 'Pictures of Health: Photographs of Medicine 1840-1980', and Dr Reginald Yorke (Maghull Health Centre) on 'Rescue and Resuscitation in Eighteenth-Century Liverpool'. For further details, please contact the Hon. Secretary/Treasurer, Mr A. R. Allan, University Archives, Arts Reading Room, Bedford Street South, P.O. Box 147, Liverpool, L69 3BX. 


\title{
THE SCOTTISH SOCIETY OF THE HISTORY OF MEDICINE REPORT OF PROCEEDINGS
}

\author{
Session 1984-85
}

The Society met on three occasions during the Session.

\section{THE THIRTY-SIXTH ANNUAL GENERAL MEETING AND THE ONE HUNDRED AND TENTH ORDINARY MEETING}

These meetings were held in the new Symposium Hall of the Royal College of Surgeons of Edinburgh on 10 November 1984. Mr J. W. Dickinson gave a paper on his ancestor John Wanless MD, a surgeon on whaling ships in the 1830s. Wanless emigrated to Canada in 1843, and his subsequent career there was described. Dr Kenneth Collins talked on 'Jewish Medical Students and Graduates at Edinburgh University, 1767-1859', giving reasons why Scotland was relatively free from the religious restrictions practised in some other countries. Dr Collins listed those Jews who had studied medicine in Edinburgh and spoke briefly on their subsequent careers.

\section{THE ONE HUNDRED AND ELEVENTH ORDINARY MEETING}

This meeting was held at Leith Hospital on 23 February 1985, when papers were read by Mr I. M. C. Macintyre, a surgeon at the hospital, and Dr J. S. Marshall, a local minister and historian. Mr Macintyre's subject was Sir David Wilkie (1882-1938), who was to become Professor of Surgery in Edinburgh in succession to Alexis Thomson. Wilkie had been appointed as surgeon to Leith Hospital in 1910. The paper outlined his contributions and noted that his influence is very much alive in modern surgical practice. Dr Marshall's title was 'Leith's Greatest Charity-The History of Leith Hospital'. He described conditions in the port which had brought about the opening of the hospital in 1851 and its subsequent development. After 1896, the hospital was freed from the burden of patients with infectious disease and underwent further extensions, including in 1926 the opening of a children's wing. The close relation between the hospital and the town of Leith was clearly portrayed.

\section{THE ONE HUNDRED AND TWELFTH ORDINARY MEETING}

This meeting was held at Dingleton Hospital, Melrose. Dr Michael Barfoot from the History of Medicine and Science Unit of Edinburgh University read a paper on the theory and practice of William Cullen, entitled 'Old Spasm'. This scholarly dissertation explored the reasons for Cullen's rather flexible approach as medicine developed during his lifetime. It was paired with a paper by Mr Eric Gilmour on 'Medicine and Music'. He looked at the medical history of musical composers including Beethoven and Tschaikowsky, commented on the therapeutic use of music, and talked briefly on the musical talents of the medically qualified. He ended a charming paper by playing a Bach Gavotte on a spinet which he had built himself. This meeting concluded the Session.

A. H. B. Masson, President

D. J. Wright, Editor, Report of Proceedings 